\title{
Experiments on direct isolation of Pythium spp. from Finnish sugar beet soils
}

\author{
MAURITZ VESTBERG \\ Department of Plant Pathology, University of Helsinki* \\ SF-00710 HELSINKI, Finland
}

\begin{abstract}
Pythium spp. were successfully isolated directly from sugar beet soils by the method of Rıcci et al. (1976). The isolates obtained were divided into four groups on the basis of morphological and growth habit characters. The groups showed large differences in in vitro pathogenicity. The importance of some factors affecting the estimation of Pythium propagule density is studied and discussed.
\end{abstract}

Index words: Pythium, direct isolation, sugar beet soils

\section{Introduction}

Scientists have developed a diversity of techniques for the isolation of Pythium spp. from soil. Fundamentally these techniques are based on two principles (Вочнот 1979): 1. Introduction of baits (living or dead plant fragments) into the soil sample, allowing each propagule of the parasite to manifest its presence by the colonization of the baits. 2 . Incorporation of soil samples into an artificial selective medium, allowing each propagule of the parasite to develop into a colony.

Baiting with plant materials has often been

* Present address: Agricultural Research Centre, Research Station of Central Finland, Juntula, SF-41340 LAUKAA, Finland used for studying specific soil fungi causing plant diseases. Materials used for detecting Pythium include apple (Hendrix \& CAMPBELL 1970), cucumber (BANIHASHEMI 1970), pineapple (KLEMMER \& NAKANO 1962), citrus leaf (Grimm \& Alexander 1970) and avocado (ZentMyer et al. 1960). Robertson (1975) developed a paper disc technique for the recovery of Pythium spp. from soil or water.

For the isolation of Pythium spp. directly from soil WARCUP's (1950) soil-plate method, in which soil is dispersed in agar, has proved superior to the dilution-plate method. RicCI and coworkers (1976) developed the soil-plate method further by transferring soil-agar discs from a primary medium to a secondary isolation medium. SCHMitTHENNER (1962) used a 
soil-particle technique for isolating Pythium ultimum Trow. and several other Pythium spp. from soil particles. Particles of 1, 3 and $7 \mathrm{mg}$ mean weight gave amounts of Pythium comparable to the soil plate technique. Angell (1954) found that Pythium was present in the larger soil particles that sedimentated from a suspension and that bacteria were present in the colloidal part. STANGHELLINI and Hancock (1970) found that $P$. ultimum grew out from small drops dispersed on the surface of 3-day-old $2 \%$ water agar and that this method could be quantified by making dilutions.

Numerous selective media have been reported for the isolation of Pythium spp. from soil. Rose bengal (Sing \& Mitchell 1961, Kerr 1963, VAartaja \& Bumbieris 1964, TAKAHASHI \& OZAKI 1965, VAarTaJA 1967 , Flowers \& Hendrix 1969, Martin 1970), gallic acid (Flowers \& HendRIX 1969) and fungicides like PCNB (VAARTAJA \& BUMBIERIS 1964, TAKahashi \& OzaKi 1965, RicCi et al. 1976) and benomyl (RICCI et al. 1976) were used in these media before the introduction of the polyene antibiotics (Tsao 1970). The polyene antibiotic pimaricin has been widely used to suppress fungi other than Pythium spp. in selective media (ECKERT \& TSAO 1960, Sing \& Mitchell 1961, Hine \& Luna 1963, Mercetich \& Fogle 1969). Several other antibiotics, eg. penicillin, polymyxin, endomycin, streptomycin, nystatin and vancomycin are also mentioned for this purpose by TSAO (1970) in his review on selective media for isolating pathogenic fungi.

This paper presents some preliminary experiments on direct isolation of Pythium spp. from Finnish sugar beet soils contaminated with the damping-off pathogen Pythium debaryanum auct. non Hesse.

\section{Materials and method}

\section{Soil}

The soil used in the various experiments were from sugar beet fields where damping- off problems had occurred. There were two very finesandy soils (Mietoinen $60^{\circ} 40^{\prime} \mathrm{N}$ $21^{\circ} 52^{\prime} \mathrm{E}$ and Laitila $60^{\circ} 56^{\prime} \mathrm{N} 24^{\circ} 40^{\prime} \mathrm{E}$ ), one clay soil from Salo $\left(60^{\circ} 21^{\prime} \mathrm{N} 23^{\circ} 4^{\prime} \mathrm{E}\right)$ and two soils were high in organic matter, a loam from Köyliö $\left(61^{\circ} 6^{\prime} \mathrm{N} 22^{\circ} 20^{\prime} \mathrm{E}\right)$ and a peaty soil from Janakkala $\left(60^{\circ} 47^{\prime} \mathrm{N} 24^{\circ} 40^{\prime} \mathrm{E}\right)$

Soil samples were stored in semi-moist conditions at room temperature until use.

\section{Agars and chemicals}

Agar media of the following types were used in the experiments:

- Difco corn meal agar

- " potato dextrose agar

- " bacto agar

- Martin's medium (MARTIN 1950) of the following composition: agar $20 \mathrm{~g}$, peptone $5 \mathrm{~g}$, dextrose $10 \mathrm{~g}, \mathrm{KH}_{2} \mathrm{PO}_{4} 1 \mathrm{~g}, \mathrm{MgSO}_{4}$ $\times 7 \mathrm{H}_{2} \mathrm{O} 0.5 \mathrm{~g}$, Rose bengal $30 \mathrm{mg} / \mathrm{l}$ water

- SPB medium (RICCI et al. 1976): agar $25 \mathrm{~g}$, malt $1 \mathrm{~g}$, saccarose $5 \mathrm{~g}, \mathrm{Ca}\left(\mathrm{NO}_{3}\right)_{2}$ $1 \mathrm{~g}, \mathrm{KNO}_{3} 250 \mathrm{mg}, \mathrm{MgSO}_{4} \times 7 \mathrm{H}_{2} \mathrm{O} 250$ $\mathrm{mg}, \mathrm{KH}_{2} \mathrm{PO}_{4} 125 \mathrm{mg}$, citric acid $50 \mathrm{mg}$, micronutrient solution $1 \mathrm{mg} / 1$ water.

The micronutrient solution had the following composition: $\mathrm{FeSO}_{4} 1 \mathrm{~g} / 1, \mathrm{ZnSO}_{4}$ $1 \mathrm{~g} / \mathrm{l}, \mathrm{CuSO}_{4} 1 \mathrm{~g} / \mathrm{l}$ and $\mathrm{MnCl}_{2} 1 \mathrm{~g} / \mathrm{l}$ water.

Commercial fungicides in the agar media were benomyl in the form of Benlate (Du Pont) as $50 \%$ a.i. and PCNB as Avicol (Kemira) with $50 \%$ a.i.

The antibiotic pimaricin was of Dutch origin, Brocades-Stheeman \& Pharmacia.

Suspensions of fungicides and pimaricin were used immediately after preparation or after short storage in a refrigerator at $4^{\circ} \mathrm{C}$.

\section{Assessment of Pythium spp.}

The basis for the isolation of Pythium spp. is the WARCUP (1950) soil-plate method as modified by Ricci et al. (1976). In this method small amounts of soil are evenly dispersed in $2.5 \%$ water agar at $40-42^{\circ} \mathrm{C}$. Citric acid, $50 \mathrm{mg} / \mathrm{l}$, is added to the agar before auto- 
claving. After solidification of the agar, round discs of $1 \mathrm{~cm}$ diameter are cut out and transferred to a Pythium selective medium. The plates are incubated for $24 \mathrm{~h}$ at $15^{\circ} \mathrm{C}$ in darkness, after which they are exposed to normal day light and darkness. After 4 days the number of plates with mycelia of Pythium are recorded and the number of propagules per gram of dry soil is calculated according to the MPN method.

\section{Statistical interpretation, MPN method}

In some experiments the number of propagules of Pythium was calculated using the most probable number method (MPN) (Maloy \& Alexander 1958). This method is based on the appearance or non-appearance of Pythium and results are compared to the Poisson distribution. The method involves three successive dilutions for the calculation of the MPN. In the present experiments the dilution coefficient was 10 and the number of replicates also 10 .

The MPN estimates of two soil samples differ from one another at the $95 \%$ level of probability when their ratio exceeds 3.3 . The MPN estimate differs from a fixed norm at the same probability level when the mutual ratio is at least 2.3 .

\section{Patogenicity of Pythium strains in vitro}

Strains of Pythium were transferred to CMA to which had been added $500 \mathrm{ppm}$ of wheat germ oil for induction of oogonia. After 7 days 10 seeds of Monohill sugar beet were sown in each petri dish $(\varnothing 90 \mathrm{~mm})$ showing fungal growth. As control, plates with no transfers of Pythium were used. After 5 days at laboratory temperatures a disease index $\left(\mathrm{DI}_{1-10}\right)$ was calculated, given by the mean of the index for seed germination (10$1)$ and seedling death $(1-10)$.

\section{Results}

\section{Testing of methods}

Pythium spp. could not be isolated directly from soil using the selective Martin's medium with the dilution plate method, even though inhibitory substances like benomyl, streptomycin or pimaricin were used. The first experiments with the soil-plate method gave positive results in some cases and negative in others, this depending on several factors. Sieving the soil proved to be important and also even dispersal of the soil into the agar. The latter problem was solved by using a hand shaker. The soil was first poured into test tubes with melted agar at $42^{\circ} \mathrm{C}$ and thence after shaking into petri dishes. The use of sufficiently large soil samples proved important when soils of low propagule densities were tested.

The direct isolation of Pythium using the modified soil-plate method of Ricci et al. (1976) proved very successful, irrespective of the kind of agar media used (Table 1). In subsequent experiments, therefore, this method was used as the basis for estimating Pythium propagule densities of soils.

\section{Some factors affecting the isolation method}

\section{Fungal growth inhibitors}

The commonly used polyene antibiotic pimaricin inhibited the growth of six $P$. debaryanum isolates out of eight (Table 2). No growth whatsoever was observed when pimaricin was used at concentrations of 50 and 100 ppm. Reduced growth was noticed at $10 \mathrm{ppm}$. The fungicide PCNB together with benomyl inhibited completely the growth of one isolate and caused reduced growth in some others, especially when PCNB was used at $100 \mathrm{ppm}$. Two isolates from the Janakkala site showed

$$
\mathrm{DI}_{1-10}=\frac{(\text { Seed germination, 10-1) }+(\text { Seedling death, } 1-10)}{2}
$$


Table 1. Success in direct isolation of Pythium spp. from soil by different methods.

\begin{tabular}{|c|c|c|c|}
\hline Method & $\begin{array}{l}\text { Origin } \\
\text { of soil }\end{array}$ & Isolation medium & $\begin{array}{l}\text { Success in iso- } \\
\text { lating Pythium }\end{array}$ \\
\hline Dilution-plate & $\begin{array}{l}\text { Janakkala } \\
\text { Laitila }\end{array}$ & $\begin{array}{l}\text { - Martin }+50 \mathrm{ppm} \text { benomyl }+ \\
20 \mathrm{ppm} \text { pimaricin } \\
- \text { CMA } \\
\text { - PDA }\end{array}$ & - \\
\hline Dilution-plate & Laitila & $\begin{array}{l}- \text { Martin }+10 \mathrm{ppm} \text { benomyl }+ \\
100 \mathrm{ppm} \text { pimaricin }+100 \mathrm{ppm} \\
\text { streptomycin sulphate }\end{array}$ & - \\
\hline Soil-plate & Laitila & - Martin + 50 ppm PCNB & + \\
\hline Soil-plate & Laitila & - Water agar & - \\
\hline$" \quad n$ & Salo & $\begin{array}{l}- \text { Water agar }+50 \mathrm{ppm} \text { citric acid } \\
+15 \mathrm{ppm} \text { benomyl }+50 \mathrm{ppm} \text { PCNB }\end{array}$ & - \\
\hline$" \quad "$ & Salo & $\begin{array}{l}- \text { CMA }+50 \text { ppm citric acid }+15 \text { ppm } \\
\text { benomyl }+50 \text { ppm PCNB }\end{array}$ & - \\
\hline$" n$ & Mietoinen & - Martin & - \\
\hline $\begin{array}{l}\text { Soil-plate as } \\
\text { modif. by RICCI } \\
\text { et al. (1976) }\end{array}$ & Köyliō & $\begin{array}{l}- \text { Martin }+15 \text { ppm benomyl }+15 \text { ppm } \\
\text { PCNB }\end{array}$ & + \\
\hline$"$ & $"$ & $-\underset{\text { pimaricin }}{\text { Martin }+15 \mathrm{ppm} \text { PCNB }+5 \mathrm{ppm}}$ & + \\
\hline$"$ & $"$ & $\begin{array}{l}- \text { Martin }+15 \mathrm{ppm} \text { benomyl }+15 \mathrm{ppm} \\
\text { PCNB }+100 \mathrm{ppm} \text { streptomycin } \\
\text { sulphate }\end{array}$ & + \\
\hline$"$ & $"$ & $\begin{array}{l}-\mathrm{SPB}+100 \mathrm{ppm} \text { streptomycin } \\
\text { sulphate }\end{array}$ & + \\
\hline
\end{tabular}

Table 2. Growth rate of 8 isolates of Pythium debaryanum on 7 agar media. Room temperature.

\begin{tabular}{|c|c|c|c|c|c|c|c|c|c|}
\hline \multirow[t]{3}{*}{ Medium } & \multicolumn{9}{|c|}{ Daily growth rate (mm) of Pythium debaryanum } \\
\hline & \multicolumn{3}{|c|}{$\begin{array}{l}\text { Mietoinen } \\
\text { isolates }\end{array}$} & \multicolumn{3}{|c|}{$\begin{array}{l}\text { Köyliō } \\
\text { isolates }\end{array}$} & \multicolumn{2}{|c|}{$\begin{array}{c}\text { Janakkala } \\
\text { isolates }\end{array}$} & \multirow[t]{2}{*}{ Mean } \\
\hline & 1 & 2 & 3 & 1 & 2 & 3 & 1 & 2 & \\
\hline 1 & 7.5 & 7.5 & 10.0 & 11.3 & 11.3 & 11.3 & 10.0 & 10.0 & 9.9 \\
\hline 2 & 5.0 & 9.3 & 7.5 & 3.8 & 3.0 & 3.5 & 6.0 & 7.5 & 5.7 \\
\hline 3 & 0 & 0 & 0 & 0 & 0 & 0 & 4.3 & 4.0 & 1.0 \\
\hline 4 & 3.0 & 6.8 & 0 & 3.0 & 3.8 & 2.8 & 4.5 & 4.0 & 4.0 \\
\hline 5 & 0 & 0 & 0 & 0 & 0 & 0 & 4.3 & 5.0 & 1.2 \\
\hline 6 & 2.5 & 6.8 & 3.8 & 2.5 & 0 & 1.8 & 5.0 & 6.3 & 3.6 \\
\hline 7 & 2.3 & 5.0 & 3.0 & 1.3 & 0 & 2.8 & 4.0 & 5.0 & 2.9 \\
\hline
\end{tabular}

Media:

1 CMA + streptomycin sulphate $100 \mathrm{ppm}$

2 Martin's medium

3 " 3 + pimaricin $50 \mathrm{ppm}$

$4 "$ " 4 " 10 " Benlate $10 \mathrm{ppm}$

5 " " $"$ " $100 "+"$ " "

$6 "$ " 6 Brassicol $10 "+n " n$

$7 " n+\cdots " 100 "+\cdots "$ 
Table 3. The influence of storage on the content of Pythium in soil from Köyliō with sugar beet and oats as preceeding crops. Propagule densities estimated by the method of Rıcci et al. (1976). Semi-moist storage of soil at room temperature.

\begin{tabular}{|c|c|c|c|c|}
\hline \multirow{3}{*}{$\begin{array}{l}\text { Amount of } \\
\text { soil } \mathrm{mg} / \\
\text { petridish }\end{array}$} & \multicolumn{4}{|c|}{ Number of positive petri-dishes $/ 10$} \\
\hline & \multicolumn{2}{|c|}{ Sugar beet field } & \multicolumn{2}{|c|}{ Oat field } \\
\hline & $\begin{array}{c}\text { Soil tested } \\
\text { immediately }\end{array}$ & $\begin{array}{l}\text { Soil stored } \\
154 \text { days }\end{array}$ & $\begin{array}{l}\text { Soil tested } \\
\text { immediately }\end{array}$ & $\begin{array}{c}\text { Soil stored } \\
154 \text { days }\end{array}$ \\
\hline 14.0 & 10 & 10 & 9 & 10 \\
\hline 2.5 & 10 & 10 & 1 & 3 \\
\hline 0.8 & 8 & 9 & 1 & 1 \\
\hline 0.2 & 8 & 6 & 0 & 2 \\
\hline
\end{tabular}

no or only minor influence by the inhibitory agents used in this experiment.

\section{Soil properties}

Storage of the soil samples under semimoist conditions at laboratory temperatures for 154 days did not affect their contents of Pythium propagules (Table 3). Drying the soil sample for 6 days before introduction into the agar medium gave fewer propagules as compared to drying overnight, especially when potato-dextrose agar was used as the isolation medium (Table 3). On the other hand, keeping the soil in the first isolation medium for 6 days gave a higher number of propagules as compared with keeping it in this medium overnight.

\section{Evaluation of the isolation method}

The method of Ricci et al. (1976) for the direct isolation of Pythium species from soil gave somewhat differing amounts of Pythium propagules depending on the type of isolation agar used (Table 4). Consistent trends were also noticed. The amount of propagules was the highest in the Köyliö soil on each of the four isolation media. On average, the number of propagules was highest on CMA and lowest on PDA.

The direct isolation of Pythium from soil yielded several species and strains. From the sugar beet soils of Köyliö, Salo, Laitila and
Janakkala four different types of Pythium could be recovered on corn meal agar:

1. Oogonia with cell wall projections

2. " " smooth cell walls of the type $P$. debaryanum $-P$. ultimum. Mycelial growth irregular growth on CMA

3. Like type 2 , but with far more abundant mycelial growth on CMA

4. No oogonia observed. Mycelial growth radial on CMA.

Type 1 had the lowest DI in the pathogenicity test. Most of the transfers of this group showed a DI of 1 , which is the same as in the control (Fig. 1). Transfers of Pythium type 2 showed a wide diversity of pathogenicity, while the third group consisted of highly pathogenic transfers with a DI peak of 8-9. The fourth group of Pythium showed low to moderate pathogenicity.

When Pythium spp. were isolated directly from soil, sevaral slow-growing fungi oc-

Table 4. Pythium densities in four soils on four media. Estimation according to the MPN method.

\begin{tabular}{lcccc}
\hline $\begin{array}{l}\text { Origin } \\
\text { of soil }\end{array}$ & $\begin{array}{l}\text { No of Pythium propagules/g dry soil as } \\
\text { estimated by the MPN method }\end{array}$ \\
\cline { 2 - 5 } & $\begin{array}{l}\text { Martin's } \\
\text { medium }\end{array}$ & $\begin{array}{c}\text { SPB } \\
\text { medium }\end{array}$ & CMA & PDA \\
\hline Köyliō & $205 \mathrm{a}$ & $75 \mathrm{a}$ & $205 \mathrm{a}$ & $40 \mathrm{~b}$ \\
Salo & $7 \mathrm{a}$ & $2 \mathrm{~b}$ & $60 \mathrm{c}$ & $13 \mathrm{ad}$ \\
Laitila & $23 \mathrm{a}$ & $14 \mathrm{a}$ & $105 \mathrm{~b}$ & $12 \mathrm{a}$ \\
Janakkala & $20 \mathrm{a}$ & $18 \mathrm{a}$ & $50 \mathrm{a}$ & $16 \mathrm{a}$ \\
\hline Mean & $64 \mathrm{ab}$ & $27 \mathrm{a}$ & $105 \mathrm{~b}$ & $20 \mathrm{a}$ \\
\hline
\end{tabular}

Row values marked with different letters differ significantly $(\mathrm{P}<0.05)$ 


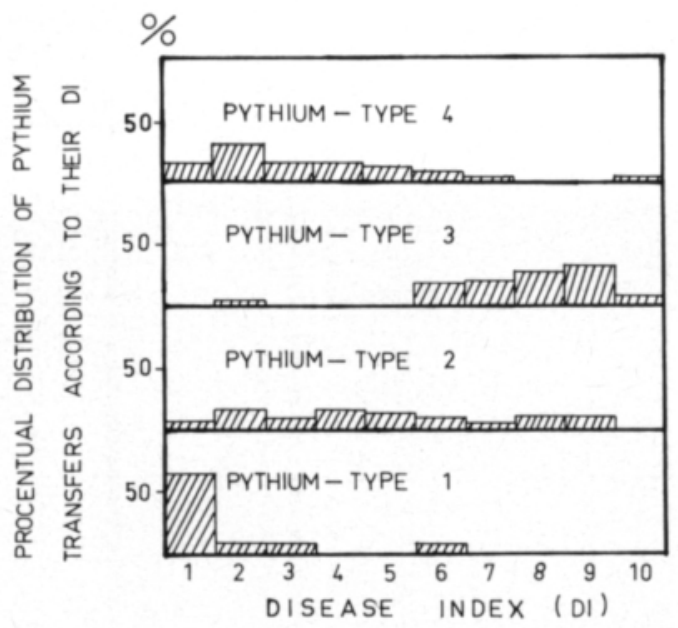

Fig. 1. Percentage distribution of four types of Pythium transfers according to their disease indices as estimated in vitro.

curred on the isolation media. In Table 5 are summarized the fungi of four sugar beet soils and their occurrence on four agar media. There were differences between the occurrence of fungi on different media. On the whole, CMA showed only a few species, this being due to the abundant growth of bacteria on this medium. Chrysosporium pannorum (Link) Hughes and Penicillium spp. were the most common fungi on Martin's medium, PDA and SPB, while for instance Acremonium spp. could be found especially on Martin's medium and SPB and Zygorhynchus spp. on Martin's medium and PDA (Table 5).

\section{Discussion}

Pythium spp. were readily isolated directly from sugar beet soils by the soil-plate method (WARCUP 1950) as modified by RicCI et al. (1976). Even common media like CMA and PDA could be used as isolation media in this method. However, cultures of Pythium obtained on MARTIN's medium (1950) and the SPB medium were more easily recognizable than cultures on CMA or PDA.

In the present investigation Pythium species were not identified, but they were grouped on the basis of morphological and growth habit characters. There were four groups of differing pathogenicity in vitro. These four groups certainly do not represent the whole Pythium flora of the soil samples studied, be-

Table 5. Occurrence of fungi other than Pythium spp. on agar media used for direct quantitative isolation of Pythium in soil. 114 petri-dishes with Martin's agar, 118 dishes with PDA, 82 dishes with CMA and 125 petridishes with SPB.

\begin{tabular}{|c|c|c|c|c|}
\hline \multirow[t]{2}{*}{ Fungus } & \multicolumn{4}{|c|}{$\begin{array}{c}\text { Number of petri-dishes showing fungal growth } \\
\text { on different media }\end{array}$} \\
\hline & $\begin{array}{l}\text { Martin's } \\
\text { agar }\end{array}$ & PDA & CMA & SPB \\
\hline Absidia sp. & 0 & 2 & 0 & 0 \\
\hline Acremonium spp. & 12 & 0 & 1 & 13 \\
\hline Alternaria alternata (Fr.) Keissl. & 2 & 1 & 0 & 0 \\
\hline Chrysosporium pannorum (Link) Hughes & 5 & 23 & 0 & 32 \\
\hline \multicolumn{5}{|l|}{ Doratomyces stemonitis (Pers. ex Steud.) } \\
\hline Morton \& G. Sm. & 0 & 1 & 0 & 4 \\
\hline Fusarium spp. & 0 & 0 & 0 & 2 \\
\hline Geotrichum candidum Link ex Leman & 3 & 0 & 0 & 0 \\
\hline Graphium sp. & 0 & 0 & 1 & 0 \\
\hline Moniliella sp. & 1 & 7 & 2 & 0 \\
\hline Monodictys levis (Wiltsh.) Hughes & 0 & 0 & 0 & 1 \\
\hline Mortierella sp. & 1 & 0 & 0 & 0 \\
\hline Mucor spp. & 1 & 2 & 0 & 0 \\
\hline Paecilomyces sp. & 2 & 0 & 0 & 0 \\
\hline Penicillium spp. & 20 & 10 & 0 & 7 \\
\hline Ulocladium botrytis Preuss & 7 & 3 & 0 & 1 \\
\hline Zygorhynchus sp. & 15 & 15 & 0 & 1 \\
\hline Unidentified fungi & 2 & 3 & 0 & 4 \\
\hline
\end{tabular}


cause only one isolation method was used. In fact, it is well known that the application of different isolation methods well yield a range of Pythium species and that no single method yields the whole Pythium flora of the soil (Hendrix \& Campbell 1973). For example, the Flowers \& Hendrix gallic acid medium is good for isolating $P$. acanthicum Drechs. P. oligandrum Drechs. group, $P$. ultimum Trow and $P$. vexans de Bary, while the Kerr medium is best for $P$. afertile Kanouse \& Humphrey, $P$. aphanidermatum (Edson) Fizp. and the $P$. dissotocum Drechs. $-P$. perniciosum Serbinow group (HENDRIX \& CAmpbell 1970). To approach a total qualitative estimate of the Pythium flora, several different techniques should therefore be used on each soil sample.

Most of the numerous Pythium-media available contain one or several antimicrobial agents. The polyene antibiotic pimaricin inhibits the growth of almost all fungi, except a small group including the pythiaceous fungi (TSAO 1970). However, reports of inhibition of some Pythiaceae fungi by pimaricin also exists (HINE 1962). In the present study, the growths of several isolates of the pathogenic $P$. debaryanum isolated from sugar beet seedlings were strongly inhibited by pimaricin. Therefore, pimaricin will not be used in further investigations. PCNB and benomyl, on the other hand, did not inhibit, or only slightly inhibited the growth of $P$. debaryanum.

The estimation of Pythium was quantified by making dilutions of test soil into water agar according to the method of Ricci et al. (1976). Although the method proved successful, it has some practical shortcomings. It is laborious and in vitro and in vivo tests are needed to separate pathogenic and nonpathogenic species or strains from each other. The method proved reliable with Pythium inoculum densities of 10 or more propagules per gram of soil. At very low densities, ie. 1 propagule or less per gram of soil, the method is not feasible because the amount of soil to be incorporated into the water agar is too high.

The number of Pythium propagules per unit of soil is only one of several factors expressing the likelyhood of plant disease. However, this knowledge might be valuable, for example, when establishing a certain minimum inoculum level above which possibilities for disease development exists.

Acknowledgements: I wish to thank Professor Eeva Tapio for critical reading of the manuscript and for her support as head of the department. I am also grateful to Dr. Kyősti Raininko (Agr. For.) and Mr. Nils Nuormala (Agronomist), who representing the Sugar Beet Research Centre, have encouraged me in my work. The English text was kindly revised by Mr. Peter Joy (M. Agr. For.).

\section{References}

ANGell, H.R. 1954. Partial segregation of bacteria and isolation of Pythium from the coarser soil fractions. Austr. J. Agric. Res. 5: 702-705.

Banihashemi, Z. 1970. A new technique for isolation of Phytophthora and Pythium species from soil. Pl. Dis. Rep. 54: 261-262.

Bочнот, D. 1979. Estimation of inoculum density and inoculum potential: Techniques and their value for disease prediction. p. 21-34. In "Soil-borne plant pathogens». Eds. Schippers, B. \& Gams, W. Academic Press. New York. 686 pp.

ECKERT, J.W. \& TSAO, P.H. 1960. A preliminaŗy report on the use of pimaricin in the isolation of Phytophthora spp. from root tissues. Pl. Dis. Rep. 44: 660-661.

Flowers, R.A. \& Hendrix, J.W. 1969. Gallic acid in a procedure for isolation of Phytophthora parasitica var. nicotianae and Pythium spp. from soil. Phytopath. 59: $725-731$.

Grimm, G.R. \& AleXander, A.F. 1970. Citrus leaf pieces as trap for soil-borne Phytophthora spp. Phytopath. 60: 1294.

Hendrix, F.F. Jr. \& Campbell, W.A. 1970. Distribution of Phytophthora and Pythium species in soils in the Continental United States. Can. J. Bot. 48: 377-384.

HINE, R. 1962. Effect of streptomycin and pimaricin on growth and respiration of Pythium species. Mycologia 54: $640-646$.

HiNe, R.B. \& LUNA, L.V. 1963. A technique for isolating 
Pythium aphanidermatum from soil. Phytopath. 53: $727-728$.

KerR, A. 1963. The root rot-Fusarium wilt complex of peas. Austr. J. Biol. Sci. 16: 55-69.

Klemmer, H.W. \& NaKano, R.Y. 1962. Techniques in isolation of Phythiaceous fungi from soil and diseased pineapple tissue. Phytopath. 52: 955-956.

MARTIN, J.P. 1950. Use of acid, rose bengal and streptomycin in the plate method for estimating soil fungi. Soil Sci. 69: 215-232.

Mercetich, S.M. \& Fogle, H.W. 1969. Role of Pythium in damping-off of peach. Phytopath. 59: 356-358.

Ricci, P.; Toribio, J.A. \& Messiaen, C.M. 1976. I La dynamique des populations de Pythium dans les sols Maraîchers de Guadeloupe. Méthodes d'étude. Ann. Phytopath. 8: 51-63.

Robertson, G.J. 1975. A paper disc technique for the recovery of Pythium spp. from soil or water. N.Z. J. Agric. Res. 18: 409-410.

SCmitthenner, A.F. 1962. Isolation of Pythium from soil particles. Phytopath. 52: 1133-1138.

\section{SELOSTUS}

\section{Pythium-sienen suora eristäminen suomalaisista sokerijuurikasmaista}

\section{Mauritz Vestberg \\ Helsingin yliopiston kasvipatologian laitos}

Vuodesta 1978 alkaen on Helsingin yliopiston kasvipatologian laitoksen ja Sokerijuurikkaan Tutkimuskeskuksen vălisenä yhteistyönă tutkittu sokerijuurikkaan taimipoltetta. Tămă kirjoitus käsittelee taimipoltteen tärkeimmän aiheuttajan, Pythium-sienen eristämistă maasta. Pythium-sientä pystyttiin eristämäăn maasta ranskalaisella menetelmällă, jossa pieniä määriă kuivaa ja seulottua maata $(3,30,300$ ja $3000 \mathrm{mg})$ sekoitettiin $42^{\circ} \mathrm{C}$ :een vesiagariin. Jăhmettyneestä agarista siirrettiin n. $1 \mathrm{~cm}$ kokoisia agarkiekkoja multineen petrimaljoihin Martinin alustalle, johon oli lisătty benomyyliä ja PCNB:tä muiden paitsi Pythium-sienen kasvun hidastamiseksi. Petrimaljat pidettiin ensin $1 \mathrm{vrk}$ pimeăssä $+15^{\circ} \mathrm{C}$ :een lämpötilassa ja tămăn jălkeen 5 vrk normaaleissa laboratorioolosuhteissa. Tămăn jälkeen tehtiin havainnot mahdollisista Pythium-kasvustoista. Saatujen lukujen perusteella
Sing, R.S. \& Mitchell, J.E. 1961. A selective method for isolation and measuring the population of Pythium in soil. Phytopath. 51: 440-444.

Stanghellini, M.E. \& Hancock, J.G. 1970. A quantitative method for the isolation of Pythium ultimum from soil. Phytopath. 60: 551-552.

TAKAHASHI, N. \& OzaKı, T. 1965. Ecological and taxonomic studies on Phythium as pathogenic soil fungi. IV The isolation methods of Pythium. Bull. Univ. Osaka Prefect., Ser. B 17: 1-10.

Tsao, P.H. 1970. Selective media for isolation of pathogenic fungi. Ann. Rev. Phytopath. 8: 157-186.

VAARTAJA, O. 1967. Reinfestation of streilized nursery seedbeds by fungi. Can. J. Microbiol. 13: 771-776.

W ARCUP, J.H. 1950. The soil-plate method for isolation of fungi from soil. Nature 166: 117-118.

Zentmyer, G.A., Gilpatrick, J.D. \& Thorn, W.A. 1960. Methods of isolating Phytophthora cinnamomi from soil and from host tissue. Phytopath. 50: 87.

Ms received September 9, 1985

laskettiin năytteille todennäköisin itiőtiheys/g ilmakuivaa maata.

Kăytetyllä menetelmällă saatiin tutkituista juurikasmaista esiin sekă tautia aiheuttavia ettă saprofyyttisiä lajeja ja kantoja. Nämä jaettiin morfologisten ja kasvutapaominaisuuksiensa perusteella neljäăn ryhmaaăn. Ryhmien vălillä todettiin patogeenisuuseroja.

Yllă selostetulla menetelmăllă saatu tieto on kăyttơkelpoista esim. verrattaessa käsittelyjă keskenaaăn tai määritettäessä sită alinta Pythium-sienen määräă, jonka ylăpuolella taimipoltteen puhkeamisvaara kasvaa. Tällă menetelmällä on myös haittapuolensa. Hyvin alhaisia Pythium-sienen itiötiheyksiä ei voida mäărittăă luotettavasti. Patogeenisten lajien ja kantojen erottaminen saprofyyttisistă vaatii laajoja laboratorio- ja kasvihuonekokeita. 